\title{
EFFECTIVENESS OF COCOA (Theobroma Cacao $L$.) SEED EXTRACT ON THE GROWTH OF IN VITRO MALASSEZIA FURFUR
}

\author{
Fajar Daniswara Montana', Yuni Setyaningsih"), Fajriati Zulfa²) \\ 1)Faculty of Medicine, Universitas Pembangunan Nasional "Veteran" Jakarta \\ 2) Department of Parasitology, Faculty of Medicine, \\ Universitas Pembangunan Nasional "Veteran" Jakarta
}

\begin{abstract}
Background: Pityriasis versicolor or Tinea versicolor is a skin disease caused by the Malassezia furfur which is often found in Indonesia. People can use anti-fungal drugs to treat this disease. However, long-term use of anti-fungal drugs is relatively more expensive and can have side effects for its users. Cocoa bean husk contains flavonoids, saponins, and alkaloids which have anti-fungal effects. This study aimed to determine the antifungal effectiveness of the cocoa bean husk extract on the growth of $M$. furfur.

Subjects and Methods: This was an experimental study using cocoa bean husk extract with a concentration variance of $25 \%, 50 \%, 75 \%, 100 \%$, with a positive control for ketoconazole $2 \%$ and a negative control using distilled water. The test was carried out by the well diffusion method using Sabouraud Dextrose Agar media. The inhibition of fungal growth was calculated by looking at the clear zone formed after 48 hours. Data were analyzed using Kruskal-Wallis and Post hoc Mann Whitney statistical tests.

Results: The mean diameter of the inhibition zone at a concentration of $25 \%, 50 \%, 75 \%$ and $100 \%$ was $3.42 \mathrm{~mm}, 4.07 \mathrm{~mm}, 4.9 \mathrm{~mm}$, and $7.3 \mathrm{~mm}$, respectively, and it was statistically significant $(\mathrm{p}=0.001)$.

Conclusion: Cocoa bean husk extract has weak anti-fungal effectiveness at concentrations of $25 \%, 50 \%$, and $75 \%$, while at $100 \%$ it has moderate effectiveness.
\end{abstract}

Keywords: antifungal, Pityriasis versicolor, cocoa bean shell, well diffusion, Malassezia furfur

Correspondence:

Yuni Setyaningsih. Department of Parasitology, Faculty of Medicine, Universitas Pembangunan Nasional "Veteran" Jakarta.

The $7^{\text {th }}$ International Conference on Public Health Solo, Indonesia, November 18-19, 2020 369 https://doi.org/10.26911/the7thicph.05.01 